ORIGINAL ARTICLE

\title{
Personal identity among adolescents from transnational families
}

\author{
Justyna Michatek $k^{1 \cdot A, B, C, D, E, F, G}$, Teresa Rostowska ${ }^{2 \cdot A, D, E, F, G}$ \\ 1: Department of Psychology of Development and Education, University of Warmia and Mazury in Olsztyn, Poland \\ 2: Institute of Psychology, University of Gdansk, Gdansk, Poland
}

\section{BACKGROUND}

Parents' labour migration generates new types of families - transnational family, where one parent or both parents migrate and leave their children behind. Separation with parents could influence the child's psychosocial functioning. The aim of this study was to analyse the situation of adolescents who experience separation from their parent/ parents caused by labour migration, especially how temporary absence of the parent is associated with the adolescents' personal identity.

PARTICIPANTS AND PROCEDURE

Participants were 99 high school youth from transnational families and 76 from non-transnational families who were asked to fill out the following measures: Identity Development Scale (U-GIDS) (Meeus, 1996; Rostowski, 1997), the interview questionnaire to collect information about parents' migration.

\section{RESULTS}

The migration factor differentiates: occurrence of personal identity statuses - in the area of interpersonal relationships (with parents and peers) and school.

\section{CONCLUSIONS}

Separation from a parent caused by labour migration is linked to occurrence of personal identity statuses.

KEY WORDS

personal identity; parent's migration; transnational family; adolescents 


\section{BACKGROUND}

Emigration (seasonal, temporary) has become a typical phenomenon in Poland, especially after the accession to the European Union in 2004 (Kępińska, 2006). Family plays an important role in the decision about migration. The new migration economy theory emphasizes that migration should be treated as a family strategy. According to that theory, migration is something else than looking for economic profits (Haug, 2008). Family changes when the whole family migrates, but also when one family member migrates. Labour migration generates new types of families and leads to 'temporary abandoned' children and other family members (Bryceson \& Vuorela, 2002). Recent research has discovered that these families are distinguished by specific patterns of communication or emotional climate and that parent-child separation influences the child's emotional and psychosocial functioning, especially at a young age, though few studies concern the situation of adolescents (Lialiugene \& Rupshene, 2008; Olwig, 1999; Parreñas, 2008).

Parenting from a distance has emotional ramifications both for parents who leave and children who are left behind. The pain of family separation creates various feelings, including helplessness, regret, and guilt, but on the other hand it offers great opportunities for a better financial living standard (Danilewicz, 2006). Previous research has focused on transnational families from classic societies of immigration (e.g. USA). In Europe, research on parents' labour migration started about two decades ago (Bryceson \& Vuorela, 2002; Olwig, 1999).

According to recent studies, the following factors can influence the children's experiences of parental separation: how family was functioning before and after migration. Moreover, it is important who migrates as the most emotional difficulties are caused by mother's migration both for children and the mother (or both parents' migration, but it is a less common situation). Relationships between family members and type of attachment are also mentioned as factors that influence child's experience of parent's migration. Children's reactions also depend on their individual characteristics like age, gender, personality and temperament traits or cognitive skills. Some studies indicated that social support network could prevent or minimize emotional damage caused by parent's migration (Gizicka, Gorbaniuk \& Szyszka, 2010; Kozak, 2010; Tomşa, 2010).

Previous studies have focused mostly on young children, only few studies have concerned the adolescents (Walczak, 2009). From a psychological point of view, adolescence is essential for personal identity development. According to Erikson's theory (1968), at this stage of the life-cycle, a young person needs to find answers to the following questions: who am I? or who can I be? Factors influencing the personal identity development include developmental patterns of change; demographic characteristics (age, gender, location, etc.); cognitive development as well as personality traits; and environmental, especially family context. The importance of the family in the formation of personal identity has already appeared in Erikson's theory and other studies (Steinberg \& Silk, 2002; Koepke \& Denissen, 2012).

The psychological crisis of late adolescence was postulated to be identity versus identity diffusion (Erikson, 1968; Marcia, 1980). Faced with the imminence of adult tasks (getting a job, becoming a citizen, and planning marriage), the late adolescent must relinquish the child's position of being given to and prepare to be the giver. The most commonly used conceptualization of Erikson's identity theory is Marcia's identity status paradigm (1980). Based on Erikson's ideas, two criteria for the presence of identity formation were proposed by Marcia: exploration and commitment (continued also by Meeus, 1996). Exploration referred to some period of re-thinking, sorting through, and trying out various roles and life plans. While commitment referred to the degree of personal investment in the individual expressed in a course of action or belief. Based on the combination of these identity processes it is possible to distinguish specific identity statuses. The least complex and mature of the four identity statuses is identity diffusion. Identity diffusions have a weak or non-existent exploratory period and an inability to make definite commitments or have not yet made (nor is attempting/willing to make) a commitment. The second status is identity foreclosure, in which the adolescent seems willing to commit to some relevant roles, values, or goals for the future. Adolescents in this stage have not experienced an identity crisis. They tend to conform to the expectations of others regarding their future. Identity moratorium is the status in which the adolescent is currently in a crisis, exploring various commitments and is ready to make choices, but has not made a commitment to these choices yet. The fourth and most mature identity status is identity achievement, in which the adolescent has gone through an identity crisis and has made a commitment to a sense of identity (i.e. certain role or value) that he or she has chosen (Meeus, 1996; Marcia, 1980).

The objective of this study was to analyze the situation of adolescents who experience separation from a parent or both parents caused by labour migration (taking into account the adolescents' gender), especially how the change in the family system (temporary absence of the parent or both parents) is associated with the adolescents' personal identity in the domains of relationships with parents, relationships with peers, ideology, school (taking into account variables such as adolescents' gender, migrating parent's gender and family structure). 
The following research hypotheses were examined:

1. Transnational family type (with a migrating mother, father or both parents) and adolescents' gender differentiate occurrence of identity statuses (in the four domains).

2. Family type (transnational vs non-transnational) and adolescents' gender differentiate occurrence of identity statuses (in the four domains).

\section{PARTICIPANTS AND PROCEDURE}

\section{PARTICIPANTS}

Participants were 99 high school youth in late adolescence $(M=18.12$ years, $S D=0.85)$ from transnational families, where a mother, father or both parents migrate abroad to work. In this group, 82 adolescents come from families where the father migrates (76 from a nuclear family; 2 - reconstructed; 5 - divorced), 10 adolescents from a family where the mother migrates ( 2 from nuclear families; 5 - divorced; 2 - single parent, because of death of a parent); 7 where both (all of them were nuclear). Most parents migrated to Germany, the Netherlands, then to Scandinavia, France, Great Britain, only approximately $6 \%$ migrated outside Europe. They had been working abroad an average of 7 years. According to recent studies, there could be different consequences for each type of transnational families, sample of adolescents from families where the mother or both parents migrated was not enough to perform a quantitative analysis (data were used in a qualitative analysis). To perform quantitative analyses, 76 students (46 females and 30 males) were selected who satisfied the conditions: only one parent (the father) migrates and they come from nuclear families. The analyses also included a match-pair comparison group consisting of 76 participants (46 females and 30 males) from nuclear non-transnational families.

\section{PROCEDURE}

Prior to initiating the study, permission from the school principals to administer the questionnaires was obtained. Necessary consent was obtained from participants or their parents (for underage students). The parents were provided with written information about the research and asked for their consent. After receiving parental permission, the students were informed about the study and asked whether they wished to participate. Approximately 200 students out of 3,700 came from transnational families, where one or both parents were working abroad for more than 1 year. Only 99 students participated in the study, mostly parents of the other students did not give con- sent. Interviewers then visited the schools and asked adolescents to fill out the questionnaire packet.

\section{MEASURES}

Identity statuses. Personal identity was assessed with the Identity Development Scale (U-GIDS) by Meeus (Polish adaptation - Rostowski, 1997). With this instrument, 5-point Likert-scale items, with a response format ranging from 1 (completely untrue) to 5 (completely true), are used to assess two identity dimensions: commitment and exploration. Based on the combination of these identity processes it is possible to distinguish specific identity statuses (diffusion, foreclosure, moratorium, achievement) in four different domains: relationship with parents, relationship with peers, school and ideology. Cronbach's alpha in the current study ranged from 0.70 to 0.93 .

Parents' migration. The interview questionnaire prepared by authors was used to collect demographic data and information about parent's migration such as who and where migrates, how long the parent works abroad, etc.

\section{RESULTS}

The first aim of this study was to compare adolescents' personal identity from different types of transnational families with the migration of the mother, father or both parents. Due to the insufficient sample size of families with the migrating mother and both parents, Table 1 presents only the distribution of identity statuses among adolescent from transnational families.

The distribution of identity statuses indicated that in the domain of relationship with parents there were no daughters in the separation from the mother and both parents who reached identity achievement, whereas in the situation of separation from the father, most of girls mostly reached the mature identity. For sons it was a different pattern - when the father migrated, sons were more likely described by identity diffusion, but when the mother or both parents migrated, sons more often reached identity achievement.

In the domain of relationship with peers, girls in separation from the father reached more often identity achievement, whereas any girls in separation from the mother or both parents reached the most mature identity (they were more often described by diffusion or foreclosure). Boys without daily contact with the father rather reached identity diffusion $(60 \%)$, but also identity achievement (22\%). However, in the situation of the mother or both parents' migration there were no sons with mature identity.

In school's domain, generally girls reached higher statuses - moratorium and achievement (in the fam- 
Table 1

Personal identity statuses distribution in four domains for females and males from different types of transnational families

\begin{tabular}{|c|c|c|c|c|c|c|c|c|}
\hline \multirow[t]{2}{*}{$\begin{array}{c}\text { Domains of identity } \\
\text { development }\end{array}$} & \multirow[t]{2}{*}{ Gender } & \multirow[t]{2}{*}{$\begin{array}{l}\text { Identity } \\
\text { Status }\end{array}$} & \multicolumn{2}{|c|}{ Mother } & \multicolumn{2}{|c|}{ Father } & \multicolumn{2}{|c|}{$\begin{array}{c}\text { Both } \\
\text { parents }\end{array}$} \\
\hline & & & $N$ & $\%$ & $N$ & $\%$ & $N$ & $\%$ \\
\hline \multicolumn{9}{|l|}{ Rel. with parents } \\
\hline & \multirow{5}{*}{ Females } & $\mathrm{D}$ & 1 & 25.0 & 9 & 18.0 & 2 & 40.0 \\
\hline & & $\mathrm{F}$ & 2 & 50.0 & 7 & 14.0 & 1 & 20.0 \\
\hline & & $M$ & 1 & 25.0 & 9 & 18.0 & 2 & 40.0 \\
\hline & & A & 0 & 0 & 25 & 50.0 & 0 & 0 \\
\hline & & $\mathrm{D}$ & 1 & 16.7 & 19 & 59.4 & 0 & 0 \\
\hline & \multirow{3}{*}{ Males } & $\mathrm{F}$ & 0 & 0 & 3 & 9.4 & 0 & 0 \\
\hline & & $M$ & 0 & 0 & 3 & 9.4 & 0 & 0 \\
\hline & & A & 5 & 83.3 & 7 & 21.9 & 2 & 100.0 \\
\hline \multicolumn{9}{|l|}{ Rel. with peers } \\
\hline & & $\mathrm{D}$ & 1 & 25.0 & 13 & 26.0 & 2 & 40.0 \\
\hline & \multirow{4}{*}{ Females } & $\mathrm{F}$ & 2 & 50.0 & 2 & 4.0 & 3 & 60.0 \\
\hline & & $M$ & 1 & 25.0 & 7 & 14.0 & 0 & 0 \\
\hline & & A & 0 & 0 & 28 & 56.0 & 0 & 0 \\
\hline & & $\mathrm{D}$ & 2 & 33.3 & 21 & 65.6 & 0 & 0 \\
\hline & \multirow{3}{*}{ Males } & $\mathrm{F}$ & 3 & 50.0 & 3 & 9.4 & 2 & 100.0 \\
\hline & & $M$ & 1 & 16.7 & 2 & 6.3 & 0 & 0 \\
\hline & & A & 0 & 0 & 6 & 18.8 & 0 & 0 \\
\hline \multicolumn{9}{|l|}{ School } \\
\hline & & $\mathrm{D}$ & 0 & 0 & 6 & 12.0 & 1 & 20.0 \\
\hline & \multirow{4}{*}{ Females } & $\mathrm{F}$ & 0 & 0 & 4 & 8.0 & 2 & 40.0 \\
\hline & & $M$ & 2 & 50.0 & 12 & 24.0 & 1 & 20.0 \\
\hline & & A & 2 & 50.0 & 28 & 56.0 & 1 & 20.0 \\
\hline & & $\mathrm{D}$ & 2 & 33.3 & 12 & 37.5 & 2 & 100.0 \\
\hline & \multirow{3}{*}{ Males } & $\mathrm{F}$ & 1 & 16.7 & 9 & 28.1 & 0 & 0 \\
\hline & & $M$ & 1 & 16.7 & 4 & 12.5 & 0 & 0 \\
\hline & & A & 2 & 33.3 & 7 & 21.9 & 0 & 0 \\
\hline \multicolumn{9}{|l|}{ Ideology } \\
\hline & \multirow{5}{*}{ Females } & $\mathrm{D}$ & 0 & 0 & 15 & 30.0 & 1 & 20.0 \\
\hline & & $\mathrm{F}$ & 0 & 0 & 12 & 24.0 & 2 & 40.0 \\
\hline & & $M$ & 1 & 25.0 & 9 & 18.0 & 1 & 20.0 \\
\hline & & A & 3 & 75.0 & 14 & 28.0 & 1 & 20.0 \\
\hline & & $\mathrm{D}$ & 2 & 33.3 & 17 & 53.1 & 0 & 0 \\
\hline & \multirow{3}{*}{ Males } & $\mathrm{F}$ & 3 & 50.0 & 4 & 12.5 & 1 & 50.0 \\
\hline & & $M$ & 0 & 0 & 4 & 12.5 & 0 & 0 \\
\hline & & A & 1 & 16.7 & 7 & 21.9 & 1 & 50.0 \\
\hline
\end{tabular}

Note. D - diffusion; F - foreclosure; $\mathrm{M}$ - moratorium; A - achievement. 
ily where the mother or father migrated), whereas in the group of boys there was no such specific pattern, only in the situation with both parents' migration - sons reached identity diffusion. In the domain of ideology there was no specific pattern either, however girls with the migrating mother did not reach diffusion or foreclosure, but rather moratorium and achievement.

Evaluation of the second hypothesis Family type (transnational vs non-transnational) and adolescents' gender differentiate occurrence of identity statuses (in the four domains) because of the sample size was possible in the group of adolescents in separation from the father. Identity statuses were treated as a categorical dependent variable - the adolescent has specific identity statuses or not. Binary codes established also were gender (coded 1 if female and 0 if male), and family type (coded to represent 1 if transnational and 0 - comparison). A log-linear model was used to test factors and their interaction in the crosstabulation (Figure 1 presents identity status distribution according to adolescent's gender and family type), separately for identity in four domains. The log-linear models indicated the distribution of identity statuses in the domains: relationship with parents, relationship with

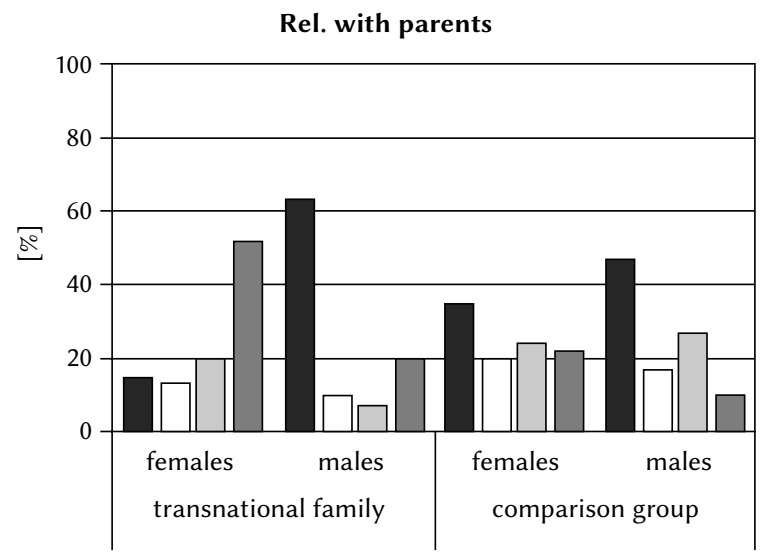

School

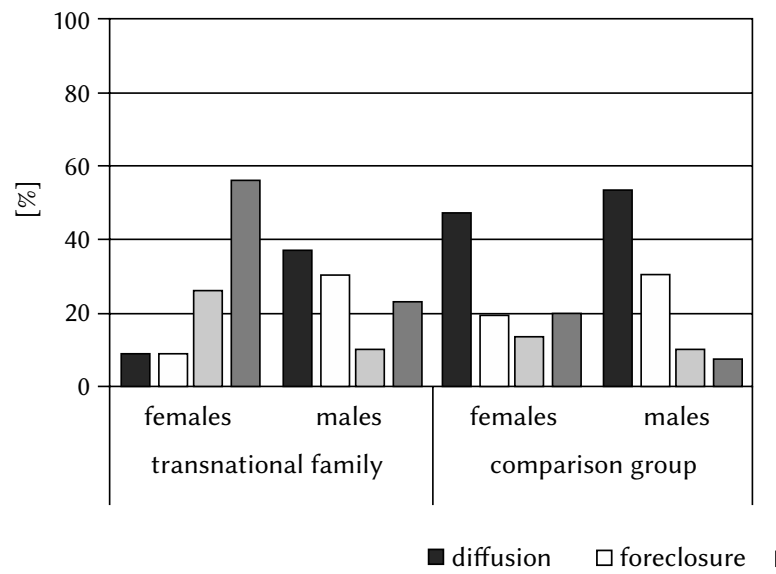

peers and school, which was described by two-way interactions: type of family $\mathrm{X}$ identity and gender $\mathrm{X}$ identity [identity in the relationship with parents: $\chi^{2}(4)=5.645, p=0.227$; identity in the domain of relationships with peers: $\chi^{2}(4)=0.885, p=0.931$; identity in the school: $\chi^{2}(4)=5.681, p=0.224$ ] (Table 2).

Analysis of marginal tables indicated that in the relationship with parents, adolescents from non-transnational families 1.5 times more were characterized by foreclosure and 1.7 times by diffusion compared with youth from transnational families. Identity achievement 2 times more likely described adolescents from transnational families. Moreover, girls reached foreclosure 2 times more often, moratorium 2 times more often and achievement 4 times more often than boys.

Analysis of marginal tables indicated that in the relationship with peers, adolescents from transnational families four times more often were characterized by identity achievement compared with youth from non-transnational families. Moreover, this status occurred 4 times more frequently among girls than boys. Four times more often females reached moratorium than males. Foreclosure 7 times more often and moratorium 2 times more often described adolescents from
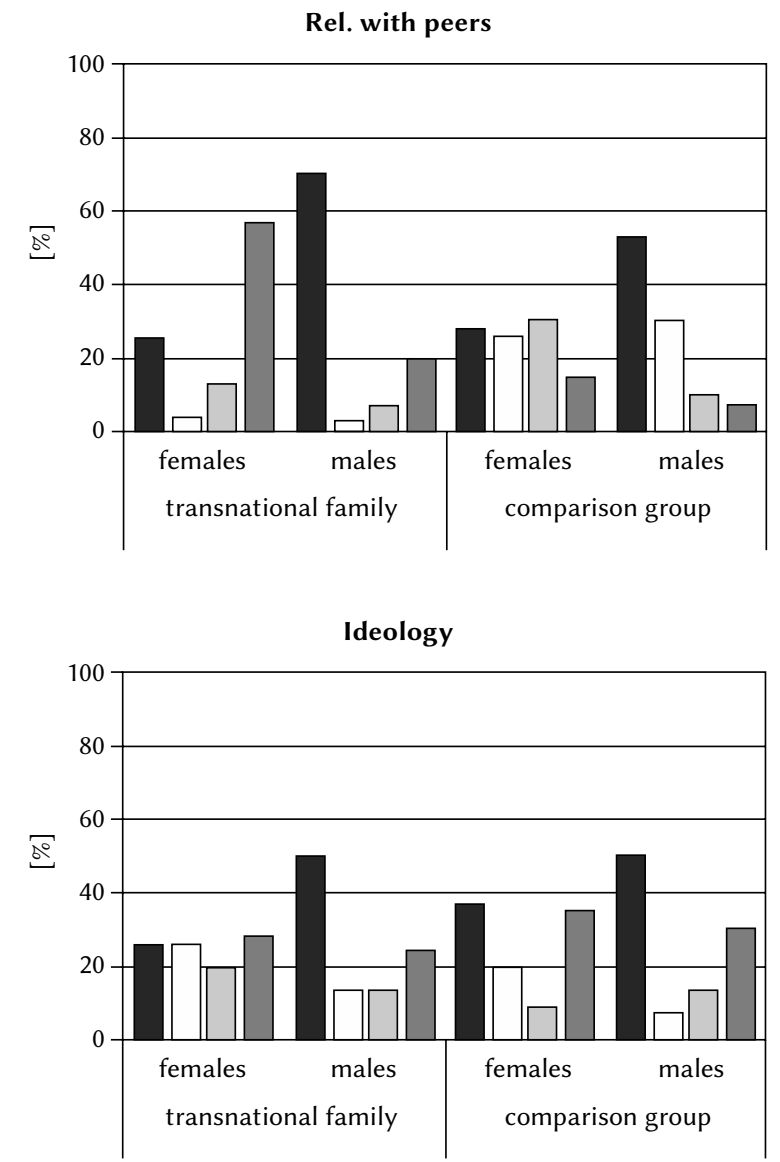

Figure 1. Distribution of personal identity statuses in four domains for females and males from two types of family (transnational - with the migrating father, and non-transnational). 
Table 2

Personal identity statuses in four domains according to the family type (transnational vs. non-transnational) and adolescent's gender (log-linear model)

\begin{tabular}{|c|c|c|c|c|c|c|}
\hline $\begin{array}{c}\text { Domains of identity } \\
\text { development }\end{array}$ & Effect & $d f$ & Partial $\chi^{2}$ & $p$ & Marginal $\chi^{2}$ & $p$ \\
\hline \multicolumn{7}{|l|}{ Rel. with parents } \\
\hline & Family type X Identity & 3 & 10.184 & 0.017 & 9.889 & 0.019 \\
\hline & Gender X Identity & 3 & 15.459 & 0.001 & 15.164 & 0.002 \\
\hline & \multicolumn{6}{|c|}{ Model parameters: $\chi^{2}=5.645 ; d f=4 ; p=0.227$} \\
\hline \multicolumn{7}{|l|}{ Rel. with peers } \\
\hline & Family type X Identity & 3 & 30.207 & $<0.001$ & 29.996 & $<0.001$ \\
\hline & Gender X Identity & 3 & 20.965 & $<0.001$ & 20.754 & $<0.001$ \\
\hline & \multicolumn{6}{|c|}{ Model parameters: $\chi^{2}=0.855 ; d f=4 ; p=0.931$} \\
\hline \multicolumn{7}{|l|}{ School } \\
\hline & Family type $X$ Identity & 3 & 25.316 & $<0.001$ & 23.043 & $<0.001$ \\
\hline & Gender X Identity & 3 & 17.962 & $<0.001$ & 15.689 & 0.001 \\
\hline \multicolumn{7}{|c|}{ Model parameters: $\chi^{2}=5.681 ; d f=4 ; p=0.224$} \\
\hline \multicolumn{7}{|l|}{ Ideology } \\
\hline & Gender & 1 & 6.443 & 0.011 & 6.443 & 0.011 \\
\hline & Identity & 1 & 22.535 & $<0.001$ & 22.535 & $<0.001$ \\
\hline & \multicolumn{6}{|c|}{ Model parameters: $\chi^{2}=10.649 ; d f=11 ; p=0.473$} \\
\hline
\end{tabular}

Note. $N=152$.

the comparison group. Diffusion identity 1.5 times more often occurred among boys than girls.

In the next domain - school, identity diffusion 2.5 times more often occurred among youth from the comparison group, whereas moratorium 2 times more often among students from transnational families. Adolescents in separation from the father caused by migration 3 times more likely reached identity achievement. Taking into account adolescents' gender, girls reached 3 times more likely moratorium and 4 times more likely identity achievement than boys.

Identity statuses in the domain of ideology were not explained by interactions between factors such as gender and family type.

In addition, because of the fact that third-way interaction effects were not significant (gender X family type $\mathrm{X}$ identity), it is not possible to draw conclusions about differences in the occurrence of identity statuses between girls and boys from transnational families (the lack of significance may be a result of a too small sample), however the distribution of identity statuses showed some pattern - girls from families with the migrating father more often reached mature statuses of personal identity, whereas boys from such families more often were characterized by diffusion identity (mainly in the two domains: relationships with parents and peers).

\section{DISCUSSION}

In general, results suggest among adolescents in separation from one parent or both parents caused by migration there are differences in the occurrence of individual identity statuses, where both adolescent's and parent's gender are important factors. However, because of the limitation of the present research, which is a small sample of adolescents with the migrating mother or both parents, statistical analysis could be performed for a group of adolescents whose fathers migrated and who came from nuclear families. The findings showed that in the domains of relationships with parents and peer and school, occurrence of identity statuses was related to the adolescents' gender and the particular type of family. In the domain of ideology there was no significant 
association between these variables. Probably the development of identity in the domain of ideology is linked to different factors, unrelated to the family (Head, 1997).

Especially for boys it is a difficult situation to grow up without a daily contact with the father. Girls stayed with their mothers, so they have their female model, as well as probably have more possibilities to become more responsible. Boys growing up without a male model showed difficulties in identity development, especially in the domains of interpersonal relationships (Benson, Harris \& Rogers, 1992; Mullis, Mullis, Schwartz, Pease \& Shriner, 2007). On the other hand, domains of interpersonal relationships seem to be more important for girls (Meeus, 1996).

In another domain of identity development school, girls mostly from transnational families generally were more likely to reach a mature identity. In contrast, the status of diffusion more often characterized young people from non-transnational families. Perhaps in transnational families values associated with work and material goods are more likely to be promoted and greater emphasis is put on issues related to the choice of school or further careers, both among boys and girls (Danilewicz, 2006).

The results of this research support the view that the family structure is important for identity development, where so far this variable has not been sufficiently analyzed. The further exploration could relate to the development of identity in the case of absence of their parents caused by other reasons, like the parents' divorce or death of a parent [some reports indicate that among girls' parents divorce and living only with the mother accelerates maturation (Mullis et al., 2007), which is consistent with the results obtained in the current study].

\section{CONCLUSIONS}

In conclusion, these findings show the importance of the family context in adolescent's personal identity development, and also the separation from parents caused by migration. However the most important limitation was an insufficient sample size of different types of transnational families. Direction for future research should include exploring the situation of a family with a migrating mother as well as both parents. Further studies with different family's structure (e.g. divorced, reconstructed, etc.) also would help understand the adolescents' identity development in the family context on a broader scale.

The first author was supported by the fellowship from the European Social Fund as part of the project "Educators for the elite - integrated training program for PhD students, post-docs and professors as academic teachers at the University of Gdansk" within the framework of
Human Capital Operational Programme, Action 4.1.1, Improving the quality of educational offer of tertiary education institutions.

This publication reflects the views only of the author, and the funder cannot be held responsible for any use which may be made of the information contained therein.

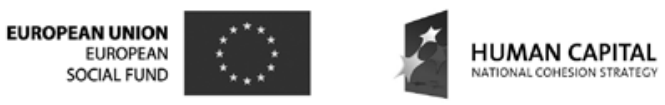

\section{References}

Benson, M.J., Harris, P.B. \& Rogers, C.S. (1992). Identity consequences of attachment to mothers and fathers among late adolescents. Journal of Research on Adolescence, 2, 187-204.

Bryceson, D. \& Vuorela, U. (eds.) (2002). The Transnational Family: New European Frontiers and Global Networks. Oxford: Berg.

Danilewicz, W. (2006). Sytuacja życiowa dzieci w rodzinach migracyjnych [Living situation of children in transnational families]. Bialystok: Wydawnictwo Trans Humana.

Erikson, E.H. (1968). Identity, youth and crisis. New York: Norton.

Gizicka, D., Gorbaniuk, J. \& Szyszka, M. (2010). Rodzina w sytuacji roztaki migracyjnej [Family in the separation caused by migration]. Lublin: Wydawnictwo KUL.

Haug, S. (2008). Migration Networks and Migration Decision-Making. Journal of Ethnic and Migration Studies, 34, 585-605.

Head, J. (1997). Working With Adolescents. London, GBR: Routledge.

Kępińska, E. (2006). Recent trends in International Migration. The 2006 SOPEMI Report for Poland. Centre of Migration Research Working Papers, No. 15/73.

Koepke, S. \& Denissen, J.J.A. (2012). Dynamics of identity development and separation-individuation in parent-child relationships during adolescence and emerging adulthood - A conceptual integration. Developmental Review, 32, 67-88.

Kozak, S. (2010). Patologia eurosieroctwa w Polsce. Skutki migracji zarobkowej dla dzieci i ich rodzin [Pathology of euro-orphanhood in Poland. The effects of migration on children and their families]. Warsaw: Difin.

Lialiugene, I.Iu. \& Rupshene, L.A. (2008). The Effect of Parents' Labor Migration on the Socialization of Adolescents. Russian Education and Society, 50, 6-19.

Marcia, J.E. (1980). Identity in adolescence. In: J. Adelson (ed.). Handbook of adolescent psychology (pp. 159-187). New York: Wiley. 
Meeus, W. (1996). Studies on Identity Development in Adolescence: An Overwiev of Research and Some New Data. Journal of Youth and Adolescence, 25, 569-598.

Mullis, A.K., Mullis, R.L., Schwartz, S.J., Pease, J.L. \& Shriner, M. (2007). Relations among Parental Divorce, Identity Status, and Coping Strategies of College Age Women. Identity: An International Journal of Theory and Research, 7, 137-154.

Olwig, K.F. (1999). Narrative of the Children Left Behind: Home and Identity in Globalised Caribbean Families. Journal of Ethnic and Migration Studies, 25, 267-284.

Parreñas, R.S. (2008). Transnational Fathering: Gendered Conflicts, Distant Disciplining and Emotional Gaps. Journal of Ethnic and Migration Studies, 34, 1057-1072.

Rostowski, J. (1997). Specyfika kształtowania się tożsamości w okresie młodości. In: J. Rostowski, T. Rostowska \& I. Janicka (eds.). Psychospoteczne aspekty rozwoju człowieka [Psychosocial aspects of human development] (pp. 159-164). Łódź: Wyd. UŁ.

Steinberg, L. \& Silk, J.S. (2002). Parenting adolescents. In: M.H. Bornstein (ed.). Handbook of parenting. Children and parenting (Vol. 1, pp. 103-133). Mahwah, NJ: Lawrence Erlbaum Associates Publishers.

Tomşa, R. (2010). Psychological Consequences of Temporary Labor Migration upon Children and Family. Petroleum - Gas University of Ploiesti Bulletin, Educational Sciences Series, 62, 206-212.

Walczak, B. (2009). Dziecko w sytuacji rozłąki migracyjnej. In: M. Duszczyk \& M. Lesińska (eds.). Wspótczesne migracje: dylematy Europy i Polski [Modern migration: the dilemmas of Europe and Polish] (pp. 149-173). Warszawa: Ośrodek Badań nad Migracjami UW. 